\title{
Structural Analysis of Reinforced Concrete Slit Shear Walls
}

\author{
Husaiba N. M. ${ }^{1}$, Elsa Paul ${ }^{2}$ \\ ${ }^{1}$ KMEA Engineering College, Edathala, India
}

\begin{abstract}
The constructions of high rise buildings are tremendously increasing worldwide. An earthquake-resistant building is required to withstand earthquakes without collapsing and without incurring major damage. Shear walls are a structural element that resists earthquake loads and wind loads in medium to high rise buildings. They are efficient lateral load resisting systems but when ductility is concerned, they are not as efficient as a structural component. Solid shear walls are very rigid structures to resist the lateral load. As the stiffness of the wall increases, the lateral load resisting capacity increases. For small intensity earthquakes, shear walls behave as rigid structures, but when high intensity earthquakes occur, plastic hinge formation takes place at the base of the wall (i.e. only a fraction of height of the wall) and hence the ductility of the rest of the wall remains untapped. So the major problems of these structural elements are: low ductility and low redundancy. The idea of introducing slits in the shear wall comes forward in this situation. Slits are introduced in the solid shear walls to act as seismic energy dissipators and convert them to flexible structures. The present study focuses on the performance of shear walls with various slit geometry by performing non-linear analysis. The work also emphasis to find the optimum slit size.
\end{abstract}

Keywords: Lateral load, plastic hinge, slits, energy dissipators, ductility.

\section{Introduction}

The constructions of high-rise buildings are rapidly increasing worldwide. An earthquake-resistant building is required to withstand earthquakes without collapsing and without incurring major damage. The inter-storey distortions also should not be excessive as this would cause extensive damage to the non-structures. To achieve these goals, the structure should have high lateral strength, ductility, high energy dissipation capacity, sufficient shear stiffness to limit inter-storey distortions, and a strategic plastification sequence such that members that are not so important for stability and are less difficult to repair will yield first, while members that are critical for stability and are difficult to repair will yield last.

Many structural forms have been developed for earthquakeresistant buildings. Of all the different forms adopted shear walls proved to be most effective. Shear walls have very high in-plane stiffness and strength, which can simultaneously resist large horizontal loads and support gravity loads, making them quite advantageous in many structural engineering applications. Generally, shear wall can be defined as structural vertical member that is able to resist combination of shear, moment and axial load induced by lateral load and gravity load transfer to the wall from other structural members. So, the shear walls serve a triple function: they support gravity load, they resists wind and earthquake loads, and they act as partitions or enclosures.

Due to their high stiffness they tends to attract large amounts of seismic energy, and as their energy dissipation capacity is low, the seismic energy absorbed may build up quickly, eventually causing excessively large seismic responses. This damage is difficult to repair because the walls carry gravity loads. It is to overcome these difficulties; the idea of introducing slits came into effect.

\subsection{Scope and Objectives}

New techniques are adopted to improve the performance of high rise structures. A structural engineer aims in designing and constructing a structure with minimum cost, in minimum time and with maximum positive response of the structure under seismic and wind hazards. The aim of this paper is a performance-based design of slitted shear walls that will ensure the life safety and viable rehabilitation from economical point of view to a building subjected to a major earthquake. The ductility of the shear wall can be increased and also RC shear walls are easy to construct in short time. The specific objectives of this study are: to compare the performance of solid shear walls with reinforced concrete slit shear walls, to determine the optimum slit geometry, to compare the crack pattern development in solid and slit shear walls and to evaluate the seismic performance of solid and slit shear walls.

\subsection{Review of Literature}

A particular reinforced concrete structural wall, with good properties of seismic energy dissipation, called slit wall, was patented by Professor K. Muto in Japan, in 1973. These walls are the first energy dissipation system used in the structures of Japan. The first building made with this system is the Keio Plaza from Tokyo (1968), a 36-storey frame structure made of steel. In the structure frameworks, vertical strips of concrete forming a slit panel are introduced. The contact between the strips is made with plaster, asbestos sheets, synthetic resin or metal plates. Seismic energy dissipation is achieved by destroying the connection between the reinforced concrete strips. Muto (1973)[3], invented a composite-flexible-rigid building structure comprising a flexible skeleton structure and a plurality of bearing wall members having slits formed therein. Each slit wall member normally acts as a rigid frame structure, and has a large ductility so as to absorb a large amount of seismic energy 


\section{International Journal of Science and Research (IJSR) \\ ISSN (Online): 2319-7064}

Index Copernicus Value (2013): 6.14 | Impact Factor (2014): 5.611

after being yielded at a certain predetermined load before complete failure. Kwan et al.(1994)[5], proposed a slit shear wall system in which the connecting beams are generally much shorter than those in ordinary coupled shear walls. The results are useful for evaluating the seismic performance of reinforced concrete slit shear walls. Beena [2013][3] studied the geometry of the slits introduced in the shear walls and its performance in resisting lateral loads. They conducted a linear analysis on reinforced concrete slit shear walls by varying the width and height of the slits.

From the literature review, it is observed that there were not many studies carried out regarding the non-linear analysis of slit geometry, to find the optimum slit size.

\section{Non-Linear Static Analysis of Slit Walls}

Non-linear static analysis is a static analysis that takes into account the inelastic behavior of the structure. Non-linear properties can be of material non-linearity and geometric non-linearity. This method provides information on the strength, deformation and ductility of the structure. The present study concentrates on the geometry of slits in the shear walls. A 20 storeyed building with shear walls, whose plan area is shown in figure 1 is taken. Each storey height is $3 \mathrm{~m}$ and one of the shear walls is taken for the analysis. Shear walls without and with slits were analyzed in ANSYS 14.5.

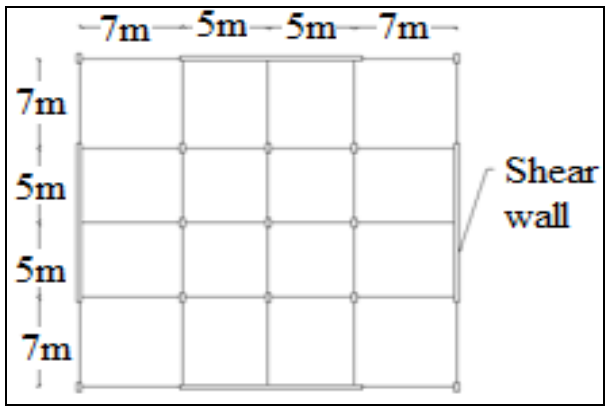

Figure 1: Plan Area of the Building

The dimensions and details of the building are given in Table 1 .

Table 1: Dimensions of the building

\begin{tabular}{|c|c|}
\hline Description & Magnitude \\
\hline Storey height & $3 \mathrm{~m}$ \\
\hline Height of the building & $60 \mathrm{~m}$ \\
\hline Thickness of shear wall & $0.40 \mathrm{~m}$ \\
\hline Number of storeys & $20 \mathrm{nos}$. \\
\hline Floor area & $24 \times 24=576 \mathrm{~m}^{2}$ \\
\hline Column and Beam sizes & $600 \mathrm{~mm} \times 300 \mathrm{~mm}$ \\
\hline Width of shear wall & $10 \mathrm{~m}$ \\
\hline
\end{tabular}

\section{Material Properties of the Shear Wall}

The concrete properties for the model are described below. There are two ways for modeling the reinforcement: discrete model and smeared model. Since the wall thickness is very small, there is no need of modelleing the reinforcement through discrete option. The smeared option is adopted here.

\subsection{Concrete Modelling}

The concrete used in this analysis is M35/40 grade concrete. The Solid 65 element was used to model the concrete. This element requires the linear isotropic and multilinear isotropic properties to properly model the concrete.The compressive uniaxial stress-strain values for the concrete model was obtained using the following equations from which the multilinear isotropic stress strain curve is obtained.

$$
\begin{gathered}
f_{c}=\frac{E_{c} \varepsilon}{1+\left(\frac{E}{x_{0}}\right)^{2}} \\
\varepsilon_{0}=\frac{2 f_{c}^{r}}{E_{r}} \quad \text { and } \quad E_{c}=\frac{f}{\varepsilon},
\end{gathered}
$$

Where $\mathrm{f}$ is the stress at any strain $\varepsilon, \varepsilon$ - strain at stress $\mathrm{f}, \varepsilon_{0}-$ strain at the ultimate compressive strength $f_{e}^{v}$. The material properties and concrete properties of M35/40 grade concrete are given in Table 2 and Table 3 below.

Table 2: Material Properties for Solid65

\begin{tabular}{|c|c|c|}
\hline \multicolumn{3}{|c|}{ Linear Isotropic } \\
\hline $\mathrm{E}_{\mathrm{c}}$ & Modulus of Elasticity & $3 \mathrm{E}+010 \mathrm{~Pa}$ \\
\hline$v$ & Poissons ratio & 0.2 \\
\hline \multicolumn{3}{|c|}{ Multilinear Isotropic } \\
\hline & Strain $\varepsilon,(\mathrm{m} / \mathrm{m})$ & Stress $\mathrm{f}_{\mathrm{c}},(\mathrm{Pa})$ \\
\hline 0 & 0 & 0 \\
\hline 1 & 0.0003 & 9000000 \\
\hline 2 & 0.0006 & 16774676.7 \\
\hline 3 & 0.0012 & 27859807.8 \\
\hline 4 & 0.0018 & 32580872.6 \\
\hline 5 & 0.00222 & 33300000 \\
\hline
\end{tabular}

Table 3: Concrete properties

\begin{tabular}{|l|l|l|}
\hline 1 & Shear transfer coefficient for an open crack & 0.4 \\
\hline 2 & Shear transfer coefficient for a closed crack & 0.8 \\
\hline 3 & Uniaxial Tensile cracking stress & $4.14 \mathrm{E}+006 \mathrm{~Pa}$ \\
\hline 4 & Uniaxial crushing stress & $3.33 \mathrm{E}+007 \mathrm{~Pa}$ \\
\hline
\end{tabular}

If the material at an integration point fails in uniaxial, biaxial or triaxial compression, the material is assumed to crush at that point. In Solid 65, crushing is defined as the complete deterioration of the structural integrity of the material (material spalling).Under conditions were crushing has occurred the material strength is assumed to be degraded and the contribution to the stiffness of an element at the integration point in question can be ignored.

\subsection{Reinforcement Modelling}

The reinforcement is added to the model through smeared option. The parameters to be considered are material number, volume ratio and orientation angle in $\mathrm{X}$ - and $\mathrm{Y}$ - directions. Volume ratio refers to the ratio of steel to concrete in element. The Table 4 shows the real constants for the concrete.

The bilinear kinematic hardening model was used. The bilinear model requires the yield stress $\left(f_{\mathrm{y}}=4.15 \mathrm{E}+02 \mathrm{MPa}\right)$ and the hardening modulus of $\operatorname{steel}\left(\mathrm{E}_{\mathrm{s}}^{\prime}=2.1 \mathrm{E}+03 \mathrm{MPa}\right)$. 


\section{International Journal of Science and Research (IJSR) \\ ISSN (Online): 2319-7064}

Index Copernicus Value (2013): 6.14 | Impact Factor (2014): 5.611

\subsection{Steel Plate Modelling}

Concentrated loads are applied at each level through steel plates. SOLID185 is used for modeling the concrete. SOLID185 is used for 3-D modeling of solid structures. It is defined by eight nodes having three degrees of freedom at each node: translations in the nodal $\mathrm{x}, \mathrm{y}$, and $\mathrm{z}$ directions. The element has plasticity, hyperelasticity, stress stiffening, creep, large deflection, and large strain capabilities.

Table 4: Real constants for concrete

\begin{tabular}{|c|c|c|c|}
\hline \multirow{2}{*}{ Particulars } & \multicolumn{3}{|c|}{ Real Constants } \\
\cline { 2 - 4 } & $\begin{array}{c}\text { Vertical } \\
\text { rebar }\end{array}$ & $\begin{array}{c}\text { Hori- } \\
\text { zontal rebar }\end{array}$ & $\begin{array}{c}\text { Vertical rebar- } \\
\text { boundary element }\end{array}$ \\
\hline Material number & 2 & 2 & 2 \\
\hline Volume ratio & 0.00513 & 0.00377 & 0.0308 \\
\hline Orientation angle, $\Theta$ & 90 & 0 & 90 \\
\hline Orientation angle, $\varnothing$ & 0 & 90 & 0 \\
\hline
\end{tabular}

\subsection{Loading and Boundary Conditions}

The figure 2 below shows the reinforced concrete solid model used for the analysis. The structural wall is fully restrained at the base. The slits will be provided in this solid model and the results are then compared. Push over analysis is carried out to find the optimum slit size. Lateral forces and the base shear acting on each storey are calculated as per IS 1893:2002 and the forces are then applied.

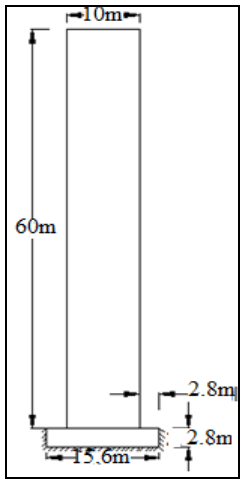

Figure 2: Reinforced concrete solid shear wall

\subsection{Design parameters(As per IS 1893: 2002)}

The building is situated in Delhi,i.e, in Zone IV.

Zone Factor, $(\mathrm{Z})=0.24$

Importance factor, $(\mathrm{I})=1.5$

Response reduction factor $(\mathrm{R})=4.0$

\subsubsection{Seismic weight of the building $(W)$ :}

As per codal provisions, the percentage of design live load to be considered for the calculation of earthquake forces is $25 \%$ for the floors, and live load for the roof is not to be accounted for.

Dead load per unit area of the floor $=4 \mathrm{kN} / \mathrm{m}^{2}$.

Weight of partitions on floor $\quad=2 \mathrm{kN} / \mathrm{m}^{2}$

Intensity of Live load on each floor $=3 \mathrm{kN} / \mathrm{m}^{2}$

Intensity of Live load on roof $\quad=1.5 \mathrm{kN} / \mathrm{m}^{2}$

The effective weight at each floor $=4+2+(0.25 \times 3)$

Effective weight on roof
Weight of 40 beams, at each floor and roof

$$
\begin{aligned}
& =0.3 \times 0.6 \times(7 \times 20+5 \times 20) \times 25 \\
& =1080 \mathrm{kN}
\end{aligned}
$$

Weight of 25 columns at each floor

$$
\begin{aligned}
& =0.3 \times 0.6 \times 2.4 \times 25 \times 25 \\
& =270 \mathrm{kN}
\end{aligned}
$$

Weight of columns at roof<smiles>C=[V][Te]</smiles>

$=135 \mathrm{kN}$

Plan area of the building

$=24 \times 24$

$=576 \mathrm{~m}^{2}$

Equivalent load at roof level

$=4 \times 576+1080+135$

$=3519 \mathrm{kN}$

Equivalent load at each floor $=6.75 \times 576+1080+270$

$=5238 \mathrm{kN}$

Seismic weight of the building, $\mathrm{W}=3519+19 \times 5238$

$=103041 \mathrm{kN}$

\subsubsection{Base Shear and lateral forces at each floor}

The fundamental natural period of vibration, $\mathrm{T}$ for the buildings having shear walls is given by,

$$
\mathrm{T} \quad=\frac{0.09 h}{\sqrt{d}}=\frac{0.09 \times 60}{\sqrt{24}} \quad=1.1
$$

For 5\% damping and type 1 soil, average response acceleration coefficient, $\frac{s_{a}}{g}=1.81$

Design horizontal seismic coefficient,

$$
\begin{array}{r}
\mathrm{A}_{\mathrm{h}}=\frac{z I S_{\mathrm{g}}}{2 \mathrm{Rg}} \\
=\frac{0.24 \times 1.0 \times 1.91}{2 \times 4} \\
=0.0543
\end{array}
$$

Base shear, $\mathrm{V}_{\mathrm{B}} \quad=\mathrm{A}_{\mathrm{h}} \times \mathrm{W}$

$$
=1.1 \times 103041
$$

$=113345.1 \mathrm{kN}$

Design lateral forces at floor, $\mathrm{i}$

$$
\mathrm{Q}=V_{B} \times \frac{w_{i} \times h_{i}^{2}}{\sum_{j=1}^{n} w_{j} \times h_{j}^{2}}
$$

Lateral loads and shear forces at different floor level are given in Table 5 .

Table 5: Lateral forces and Base Shear at Each Storey

\begin{tabular}{|c|c|c|c|c|}
\hline Floor & $\begin{array}{c}\text { Weight } \mathrm{W}_{\mathrm{i}} \\
(\mathrm{kN})\end{array}$ & $\begin{array}{c}\text { Height } \\
\mathrm{h}_{\mathrm{i}}(\mathrm{m})\end{array}$ & $\begin{array}{c}\text { Design Lateral } \\
\text { Force, } \mathrm{Q}_{\mathrm{i}}(\mathrm{kN})\end{array}$ & $\begin{array}{c}\text { Shear } \\
(\mathrm{kN})\end{array}$ \\
\hline 20 & 3519 & 60 & 275.96 & 137.980 \\
\hline 19 & 5238 & 57 & 371.32 & 185.660 \\
\hline 18 & 5238 & 54 & 331.94 & 165.970 \\
\hline 17 & 5238 & 51 & 298.18 & 149.090 \\
\hline 16 & 5238 & 48 & 261.61 & 130.805 \\
\hline 15 & 5238 & 45 & 231.23 & 115.615 \\
\hline 14 & 5238 & 42 & 201.41 & 100.705 \\
\hline 13 & 5238 & 39 & 173.56 & 86.780 \\
\hline 12 & 5238 & 36 & 147.96 & 73.980 \\
\hline 11 & 5238 & 33 & 124.335 & 62.168 \\
\hline 10 & 5238 & 30 & 102.675 & 51.338 \\
\hline 9 & 5238 & 27 & 83.265 & 41.633 \\
\hline 8 & 5238 & 24 & 65.820 & 32.910 \\
\hline 7 & 5238 & 21 & 50.350 & 25.180 \\
\hline 6 & 5238 & 18 & 36.850 & 18.425 \\
\hline 5 & 5238 & 15 & 25.320 & 12.660 \\
\hline 4 & 5238 & 12 & 16.880 & 8.440 \\
\hline 3 & 5238 & 9 & 9.283 & 4.642 \\
\hline 2 & 5238 & 6 & 4.220 & 2.110 \\
\hline 1 & 5238 & 3 & 1.041 & 0.521 \\
\hline
\end{tabular}




\section{International Journal of Science and Research (IJSR) \\ ISSN (Online): 2319-7064 \\ Index Copernicus Value (2013): 6.14 | Impact Factor (2014): 5.611}

\subsection{Modelling and analysis results}

The meshed model of the reinforced concrete solid shear wall is shown in figure 3 below.



Figure 3: Meshed model of solid shear wall

The meshed models are applied with boundary conditions and then the gravity loads and lateral loads are applied to the model. The models are analyzed and the nodal displacement obtained is shown in figure 4 . The maximum displacement is at the top storey with deformation $110.448 \mathrm{~mm}$.



Figure 4: Nodal displacement of solid shear wall

The von-mises stress distribution of solid shear wall is shown in figure 5. The maximum stress is at the point of formation of plastic hinge which is on the compression side of the shear wall.

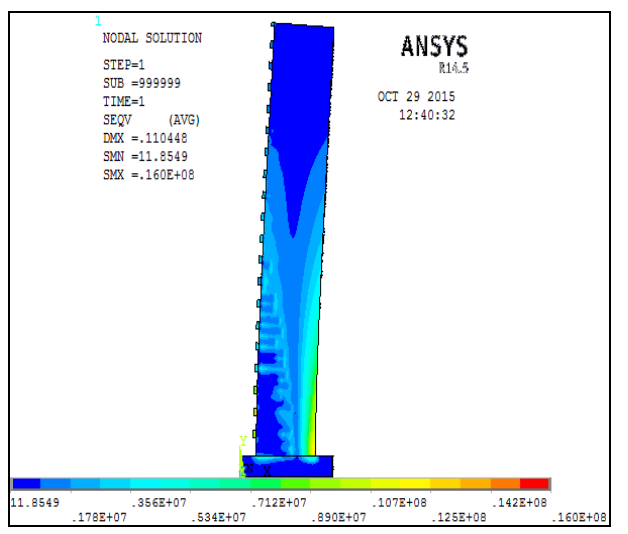

Figure 5: Von-mises stress distribution of solid shear wall
The slits are adopted in solid shear walls. The various combinations of slit dimensions considered in this study are given in Table 2 . The variables considered are width and height of the slit. The slit wall with $0.09 \mathrm{~m}$ width and $2400 \mathrm{~mm}$ height are shown in figure 6 below.

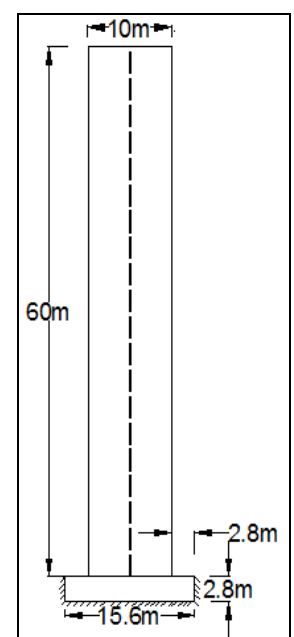

Figure 6: Slit wall model

Table 6: The details of slit dimension

\begin{tabular}{|c|c|c|c|}
\hline $\begin{array}{l}\text { Sl } \\
\text { No. }\end{array}$ & $\begin{array}{c}\text { Slit } \\
\text { Dimension }\end{array}$ & $\begin{array}{c}\text { Width of } \\
\text { Slit }, \mathrm{b}(\mathrm{m})\end{array}$ & $\begin{array}{c}\text { Height of } \\
\text { Slit }, \mathrm{h}(\mathrm{m})\end{array}$ \\
\hline 1 & $0.0 \mathrm{~B} 0.0 \mathrm{H}$ & 0.0 & 0.0 \\
\hline 2 & $0.005 \mathrm{~B} 0.5 \mathrm{H}$ & 0.05 & 1.5 \\
\hline 3 & $0.005 \mathrm{~B} \times 0.6 \mathrm{H}$ & 0.05 & 1.8 \\
\hline 4 & $0.005 \mathrm{~B} \times 0.7 \mathrm{H}$ & 0.05 & 2.1 \\
\hline 5 & $0.005 \mathrm{~B} 0.8 \mathrm{H}$ & 0.05 & 2.4 \\
\hline 6 & $0.006 \mathrm{~B} \times 0.5 \mathrm{H}$ & 0.06 & 1.5 \\
\hline 7 & $0.006 \mathrm{~B} \times 0.6 \mathrm{H}$ & 0.06 & 1.8 \\
\hline 8 & $0.006 \mathrm{~B} 0.7 \mathrm{H}$ & 0.06 & 2.1 \\
\hline 9 & $0.006 \mathrm{~B} \times 0.8 \mathrm{H}$ & 0.06 & 2.4 \\
\hline 10 & $0.007 \mathrm{~B} \times 0.5 \mathrm{H}$ & 0.07 & 1.5 \\
\hline 11 & $0.007 \mathrm{~B} 0.6 \mathrm{H}$ & 0.07 & 1.8 \\
\hline 12 & $0.007 \mathrm{~B} 0.7 \mathrm{H}$ & 0.07 & 2.1 \\
\hline 13 & $0.007 \mathrm{~B} \times 0.8 \mathrm{H}$ & 0.07 & 2.4 \\
\hline 14 & $0.008 \mathrm{~B} \times 0.5 \mathrm{H}$ & 0.08 & 1.5 \\
\hline 15 & $0.008 \mathrm{~B} 0.6 \mathrm{H}$ & 0.08 & 1.8 \\
\hline 16 & $0.008 \mathrm{~B} \times 0.7 \mathrm{H}$ & 0.08 & 2.1 \\
\hline 17 & $0.008 \mathrm{~B} 0.8 \mathrm{H}$ & 0.08 & 2.4 \\
\hline 18 & $0.009 \mathrm{~B} \times 0.5 \mathrm{H}$ & 0.09 & 1.5 \\
\hline 19 & $0.009 \mathrm{~B} \times 0.6 \mathrm{H}$ & 0.09 & 1.8 \\
\hline 20 & $0.009 \mathrm{~B} \times 0.7 \mathrm{H}$ & 0.09 & 2.1 \\
\hline 21 & $0.009 \mathrm{~B} \times 0.8 \mathrm{H}$ & 0.09 & 2.4 \\
\hline
\end{tabular}

The models are subjected to lateral loads and the nodal displacements and von-mises stress distributions are compared. It can be seen that the stresses are distributed along the slit openings throughout the wall height. The plastic hinge formation takes place after the failure of shear connections. The figure 7 below shows the nodal displacement of optimum slit sized wall with $0.09 \mathrm{~m}$ width and $2400 \mathrm{~mm}$ height. 


\section{International Journal of Science and Research (IJSR) \\ ISSN (Online): 2319-7064}

Index Copernicus Value (2013): 6.14 | Impact Factor (2014): 5.611

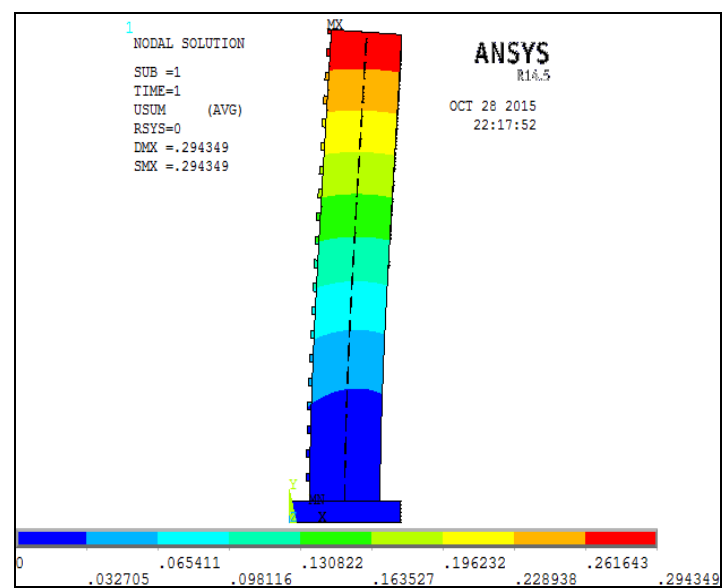

Figure 7: Nodal displacement of slit shear wall

The maximum deformation is at the top storey and the value is $294.349 \mathrm{~mm}$. The figure 8 shows the von-mises stress distribution of slit shear wall.

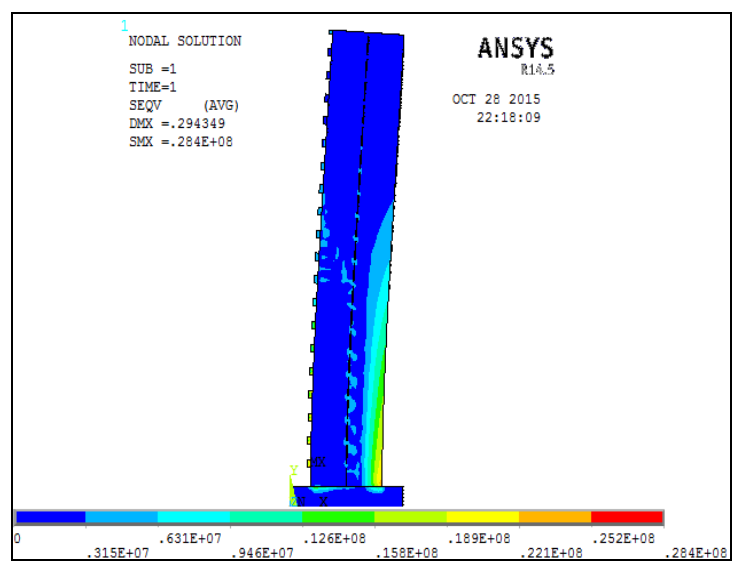

Figure 8: Von-mises stress for slit shear wall

The Table 7 below shows the results of all the slit shear walls with various openings and the wall with $0.09 \mathrm{~m}$ width and $2400 \mathrm{~mm}$ height was the optimum slit size.

Table 7: Displacement for various slit configurations

\begin{tabular}{|c|c|c|c|c|c|}
\hline Wid th & $.05 \mathrm{~m}$ & $.06 \mathrm{~m}$ & $.07 \mathrm{~m}$ & $.08 \mathrm{~m}$ & $.09 \mathrm{~m}$ \\
\cline { 2 - 6 } Height & \multicolumn{5}{|c|}{ Top Deflection in $\mathrm{mm}$} \\
\hline $1.5 \mathrm{~m}$ & 234.1 & 241.4 & 243.2 & 269.9 & 273.8 \\
\hline $1.8 \mathrm{~m}$ & 241.2 & 243.2 & 256.5 & 258.6 & 281.5 \\
\hline $2.1 \mathrm{~m}$ & 245.4 & 251.2 & 258.6 & 278.7 & 293.5 \\
\hline $2.4 \mathrm{~m}$ & 251.5 & 256.6 & 276.8 & 284.6 & 294.4 \\
\hline
\end{tabular}

The slit height when increased to $2.7 \mathrm{~m}$ showed unfavourable response of the model. The crack patterns of the models were also compared. The figure 9 below shows the cracking and crushing of solid shear walls at the bottom of the wall. The ductility of the wall is not made use of.

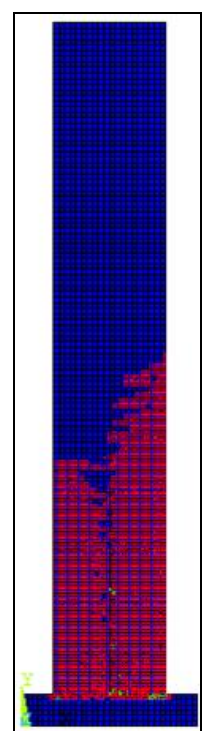

Figure 9: Cracking and crushing of solid shear wall

Figure 10 below shows the crack development of slit shear wall.

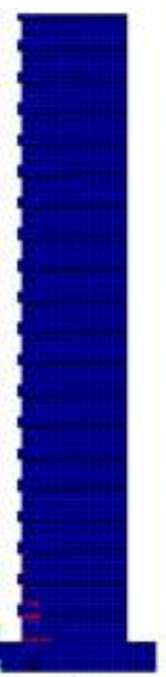

(i)

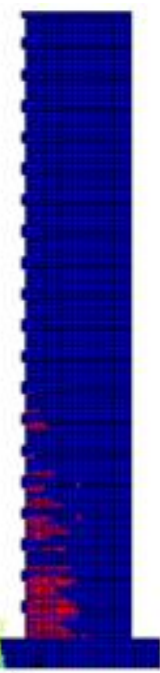

(ii)

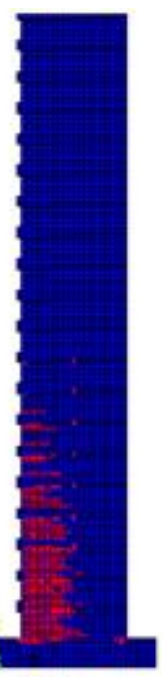

(iii)

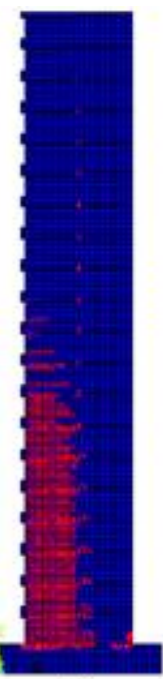

(iv)
Figure 10: Cracking of slit shear walls

The mechanism of crack development is described here:The figure 10 shows the cracking of slit shear walls.

1)First set of cracks were developed at the bottom of the wall on tension side at a load of $843.9627 \mathrm{kN}$.

2) The cracks are further extended on to the surface of wall and first cracks are observed on the shear connections , at a load of $1406.604 \mathrm{kN}$.

3) The cracks further extend on to the shear connections provided over the height of the wall as the load is increased further.

4) The final cracking and were crushing of concrete begins on the compression side of the wall at a load of $2531.888 \mathrm{kN}$ that results in ultimate failure.

Figure 11 and figure12 shows the variation of deformation with lateral load at the top storey. 


\section{International Journal of Science and Research (IJSR) \\ ISSN (Online): 2319-7064}

Index Copernicus Value (2013): 6.14 | Impact Factor (2014): 5.611

Table 8: State of cracking for solid and slit walls

\begin{tabular}{|c|c|l|}
\hline \multirow{4}{*}{$\begin{array}{c}\text { Slit } \\
\text { wall }\end{array}$} & L oad,kN & \multicolumn{1}{c|}{ State of cracking } \\
\cline { 2 - 3 } & 843.9627 & $\begin{array}{l}\text { First crack starts to appear at } \\
\text { the base of the wall }\end{array}$ \\
\cline { 2 - 3 } & 1406.604 & $\begin{array}{l}\text { First crack starts to appear in } \\
\text { shear connections }\end{array}$ \\
\cline { 2 - 3 } & 2531.888 & $\begin{array}{l}\text { Failure of the shear } \\
\text { connections }\end{array}$ \\
\hline $\begin{array}{c}\text { Solid } \\
\text { wall }\end{array}$ & L oad,kN & \multicolumn{1}{|c|}{ State of cracking } \\
\cline { 2 - 3 } & 562.6418 & $\begin{array}{l}\text { First crack starts to appear at } \\
\text { the base of the wall }\end{array}$ \\
\cline { 2 - 3 } & 1403.1 & Failure of the solid wall \\
\hline
\end{tabular}

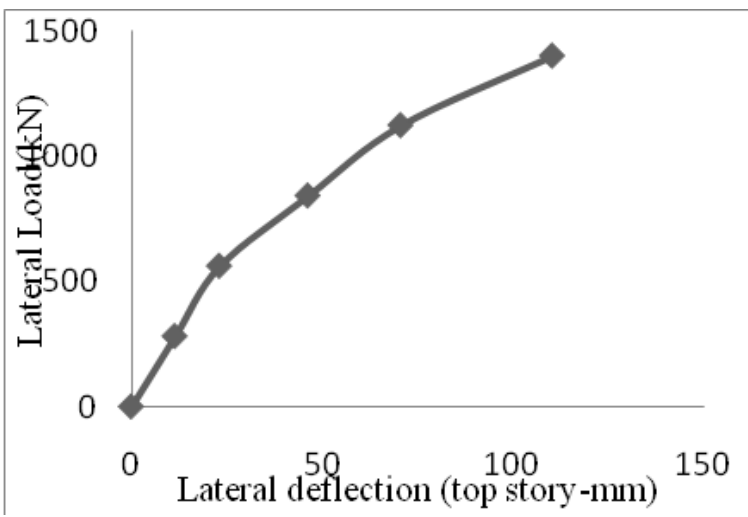

Figure 11: Lateral Load Vs Lateral deflection of Solid wall

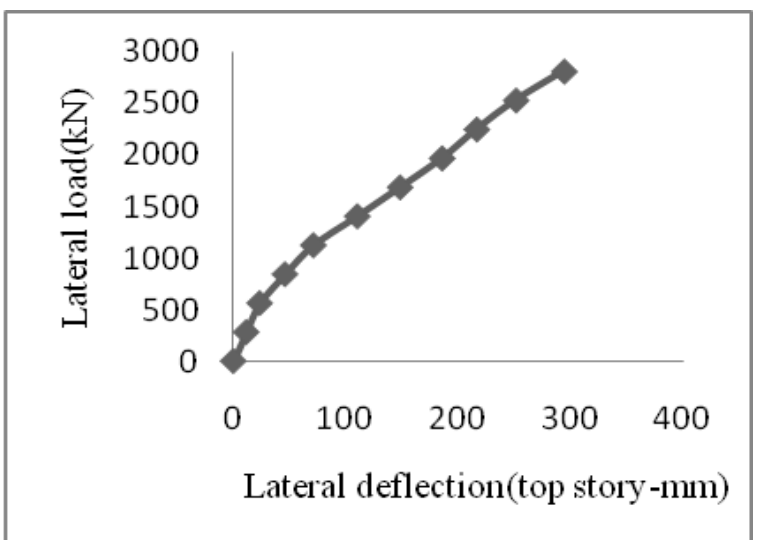

Figure 12: Lateral load Vs Top story deflection of slit wall

\section{Conclusions}

Non-linear static analysis leads to the following conclusion that as the width and height of the slit increases the flexibility of the walls are increased. In the case of solid shear walls, the ductility of the wall is not made use of, so it fails at the bottom of the wall which is difficult to repair or maintenance when subjected to severe earthquakes. By introducing slits, these damages are distributed throughout the shear connections provided along the height, so that in case of failure these shear connections can be easily replaced. The optimum slit size is with width $90 \mathrm{~mm}$ and height $2400 \mathrm{~mm}$. Slit shear wall showed better performance than solid shear walls. The cracks were distributed through the shear connections along the height.

\section{References}

[1] S. K. Duggal, Earthquake resistant design of structures, 2nd edition, Department of civil engineering, Allahabad.

[2] IS 1893(Part 1):2002, Criteria for earthquake resistant design of structures.

[3] Kiyoshi muto, Nobutsugu ohmori, Takao Itoh," Composite building structures and walls therefore", USA Patent 3736712, 1973.

[4] B.R. Beena, A.P. Shashikala, Job Thomas, T.P.Somasundaran, "Effect of slit geometry on the performance of shear wall for resisting lateral loads", American Journal of Engineering Research(AJER),Volume-2, pp-32-38,2013.

[5] A.K.H. Kwan, H.Dai, Y.K.Cheung." Elasto-plastic analysis of reinforced concrete slit shear walls", Proceedings Of The Institution Of Civil Engineers: Structures And Buildings-1998,Vol. 128, pp 317324,1994 . 